\title{
Microbial succession in white button mushroom production systems from compost and casing to a marketable packed product
}

Nazareth A. Siyoum, ${ }^{*}$ Karen Surridge, ${ }^{* *}$ Elna J. van der Linde, ${ }^{* * *}$ Lise Korsten ${ }^{*}$

${ }^{*}$ Department of Plant Science, Faculty of Natural and Agricultural Sciences, University of Pretoria, Pretoria, South Africa.

** Department of Plant Production and Soil Science, Faculty of Natural and Agricultural Sciences, University of Pretoria, Pretoria, South Africa.

**** Plant Protection Research Institute, Agricultural Research Council, P/Bag X134, Queenswood 0121 Pretoria, South Africa.

*Corresponding author:

Lise.Korsten@up.ac.za

Tel. $\quad+27124203295$

Fax $\quad+27124204588$

\begin{abstract}
The aim of the study was to investigate microbial succession in the mushroom supply chain from compost, casing to fruit body formation and mushroom growth to the point of harvested, packing and point of sale. The microbial population dynamics of compost, casing and mushrooms were determined using a plate count technique, denaturing gradient gel electrophoresis (DGGE) and sequencing of $16 \mathrm{~S}$ and $18 \mathrm{~S}$ rDNA. Plating revealed greater abundance of bacteria, fungi and yeasts in mushroom compost compared to casing and fresh mushroom samples. The viable count method also showed that bacteria and yeasts increased significantly after harvest and
\end{abstract}


during cold storage. Sequencing revealed a more diverse culturable bacterial population in casing and on the mushrooms than in the compost. Phylogenetic analysis revealed a general trend of grouping of species from the same sources. In contrast, a higher microbial diversity was recorded in compost when using the DGGE method, which reflects cultural and non- culturable microorganisms. For compost and casing bacteria studied using DGGE, several species formed separate lineages, demonstrating highly diverse communities in these samples. Fungi were shown to be less abundant and less diverse compared to bacteria and yeasts. The study provides baseline knowledge of microbial populations and -succession trends in mushroom production systems using viable and non- viable methods. The information provided in this study may be useful for microbial ecology studies and to identify and develop biocontrol systems for pathogen control during production or to enhance pinning stimulation by knowing when to apply Pseudomonas spp. to ensure increased yield. Finally an insight is provided into microbial survival during cold storage and marketing of mushrooms. Potential antagonistic populations known to prevent spoilage, quality deterioration and extend shelf life are listed in this paper.

Keywords: Agaricus bisporus, bacteria, casing, compost, fungi, microbial succession, yeasts

\section{Introduction}

White button mushrooms (Agaricus bisporus (Lange) Imbach) are commercially produced using two main substrates, compost and casing. The number of mushrooms harvested is largely affected by the microbial population dynamics and microbial succession taking place during composting (Székely et al. 2009). Similarly, the postharvest quality of mushrooms is affected by microorganisms present on the harvested product (Fett et al. 1995). Therefore, understanding 
microbial population dynamics of the substrates as well as on the mushroom surface is important to enhance production and retain quality.

Compost is a product of the natural microbial breakdown processes of different substrate materials. Mushroom compost is commercially prepared from grain straw (wheat), animal manure (from poultry) and gypsum as is commercially used in South Africa (Labuschagne, 1995). Phase I compost where substrates are mixed and self-heated after wetting is characterised by high microbial activity (Miller et al. 1989), while Phase II compost is the result of aerobic microbial activities under controlled temperature conditions (Straatsma et al. 1994). Several microorganisms are known to be associated with general composting processes of organic materials and were extensively reviewed by Ryckeboer et al. (2003a).

Casing medium that covers Phase III (spawn run) compost in mushroom beds harbours saprophytic micro-organisms. Although different fungi and bacteria were isolated from mushroom casing medium by several researchers (Hayes et al. 1969; Eicker and Greuning, 1989; Fermor et al. 2000), much of the work done focussed on bacteria. The role of bacteria in the casing medium is of importance in the process of mushroom fruit body initiation as well as in the initiation of pinning. In this layer, pseudomonads are the most commonly found bacteria associated with mushroom fruit body formation. Saprophytic pseudomonads isolated from casing medium included Pseudomonas fluorescens, Pseudomonas gingeri, Pseudomonas putida, Pseudomonas reactans and Pseudomonas tolaasii (Fett et al. 1995). Fungi in peat casing medium included Aspergillus, Penicillium, Trichoderma, Geotrichium and Chrysonilia spp. (Labuschagne, 1995). Some of these species are known to cause mushroom diseases or losses. 
Pseudomonads can also be isolated from mushroom fruit bodies; these bacteria may either be saprophytic e.g. P. reactans or pathogenic including species like Pseudomonas agarici, $P$. gingeri and $P$. tolaasii causing discoloration and other symptoms on growing mushrooms (Fett et al. 1995). The species $P$. agarici, $P$. reactans and $P$. tolaasii have also been reported responsible for postharvest browning and decay (Wells et al. 1996).

Since mushrooms are produced in close physical contact with the casing layer and the compost, the microbial ecology of the substrates could thus be interrelated with the mushroom fruit body surface microflora (Garbeva et al. 2004). A microbial profile and determination of population shifts and -succession from the mushroom substrates (compost and casing) to the harvested and packed mushroom product have not been done before as far as we could determine. The objectives of this study were therefore 1) to investigate microbial succession of dominant species and determine its diversity from commercial casing material to the mushroom fruit bodies and the final consumable product 2) to examine phylogenetic relationships between micro-organisms in substrates and the mushroom product. This information will be useful in providing baseline knowledge to develop systems to manipulate microorganisms to enhance pinning, ensure disease control and extend shelf life.

\section{Materials and Methods}

\section{Compost, casing and mushroom samples}

Samples (250 g) of compost, casing and mushrooms were collected from a commercial mushroom farm operating on standard production practices. Compost and fresh casing samples 
were collected aseptically in a randomised design in sterile plastic bags on the day mushroom beds were cased. Casing samples were further collected from the same casing lot and trays at pinning and again at first flush. Mushrooms were harvested from the same trays to measure microbial succession from casing to mushroom fruit body formation. Harvested mushrooms were commercially packed in punnets and wrapped with plastic cling film. Samples were transported back to the laboratory for immediate processing. The commercially packed product was also stored to simulate commercial retail and marketing conditions $\left(4{ }^{\circ} \mathrm{C}\right.$ storage and sampling after 4, 8 and 12 days) to ensure a farm-to-fork continuum. All samples were collected as two subsamples in eight replicates (i.e. from eight mushroom trays per sampling time) except for mushrooms collected after 12 days of cold storage, in which case only four trays were sampled. The sampling strategy was based on a larger number of smaller samples for a more complete inventory of microbial diversity according to Ranjard et al. (2003). A summary of the sampled production materials, methodologies and findings is shown in the schematic diagram in Fig 1.

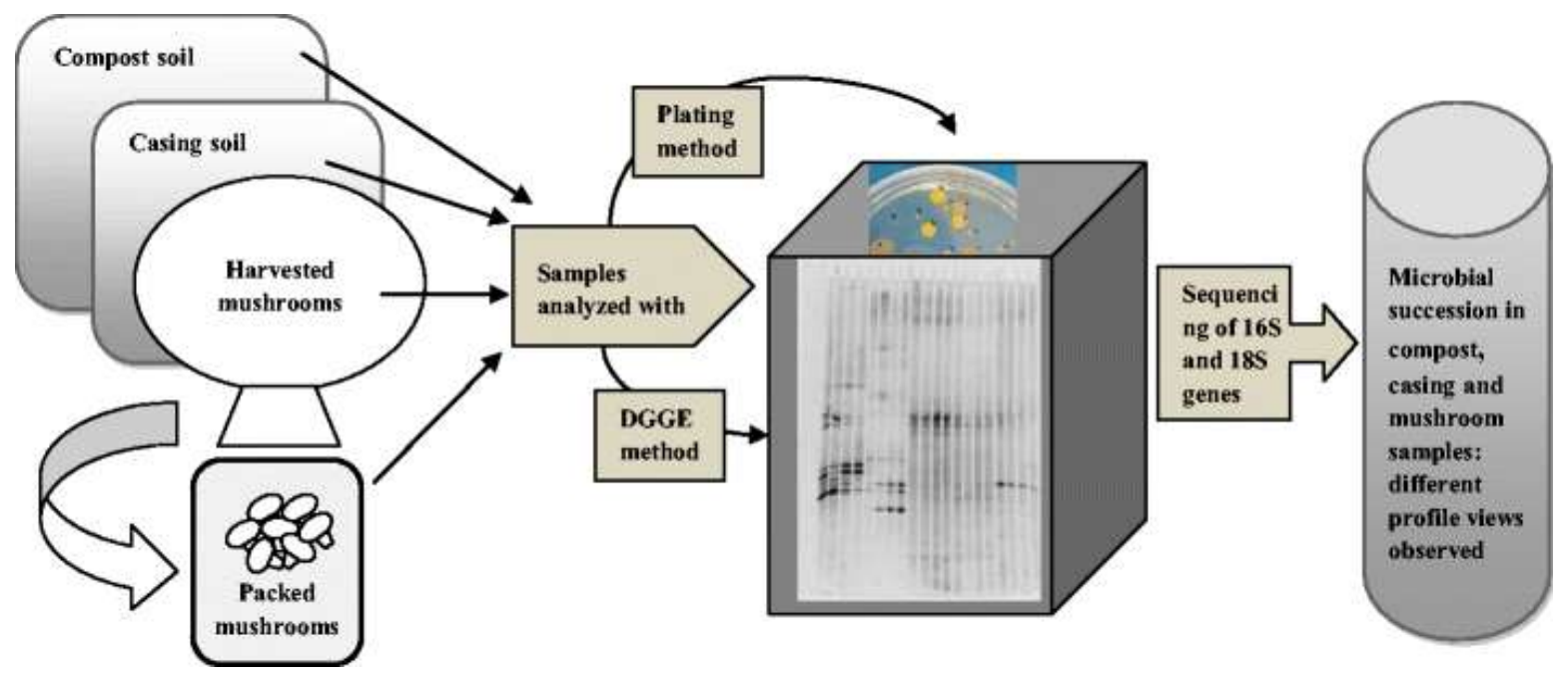

Fig. 1: Schematic diagram showing sampled materials in mushroom production systems and methods used to analyse samples in order to examine microbial successions in the system 


\section{Microbial enumeration}

Standard I nutrient agar (STD I) and malt extract agar (MEA) (Merck, South Africa) were used to isolate and culture bacteria, fungi and yeasts respectively. Ten $\mathrm{mL}$ of $0.1 \%$ cycloheximide (Sigma-Aldrich, South Africa) and a capsule of $250 \mathrm{mg}$ chloramphenicol (CAPS Pharmaceuticals, South Africa) were added per litre of STD I and MEA media to inhibit fungal and bacterial growth respectively. The spread plate technique was used to enumerate microorganisms in the casing and compost substrates as well as the mushrooms. Ten gram of the compost and casing samples were suspended in $90 \mathrm{~mL}$ of biological agar solution $(0.1 \%$ in water) (Merck). A dilution series was subsequently prepared in quarter strength Ringer's (Merck) solution, and plated onto STD I and MEA in three replicates. Mushroom samples (25 g) were blended in a sterile stomacher bag with $225 \mathrm{~mL} 0.1 \%$ peptone buffer (Merck) using a stomacher $\left({ }^{\circledR} 400\right.$ Circulator, Lasec, South Africa) for 2 min. A series of dilutions were prepared from the buffer suspension and suitable dilutions were plated. Plates were incubated at $25{ }^{\circ} \mathrm{C}$ for seven days. Colonies were counted (total colonies and diversity) and isolations made to obtain pure cultures of representative isolates. Bacteria and yeast cultures were preserved on their respective media at $4{ }^{\circ} \mathrm{C}$ and as well as in $15 \%$ glycerol stored at $-70{ }^{\circ} \mathrm{C}$. Fungi were preserved in double sterile distilled water as well as on agar slants.

\section{DNA Extraction}

Extraction of DNA from pure cultures was done using a ZR Fungal/Bacterial DNA Kit (Inqaba Biotec (Pty.) Ltd., South Africa) according to manufacturer instruction. DNA was extracted using a loop full taken from pure colonies. Total microbial DNAs were extracted for denaturing gradient gel electrophoresis (DGGE) from compost, casing and mushrooms using a ZR Soil 
Microbe DNA Kit (Inqaba Biotec) according to manufacturer instruction, with some modification. An amount of $150 \mathrm{~mL}$ of the above mentioned stomached mushroom suspension was filtered onto sterile filter paper $(0.2 \mu \mathrm{m}$ pore size; Sartorius Stedim Biotech, Goettingen, Germany). DNA was extracted from the filtrate by soaking the filter paper in a lysis solution. To increase DNA yield of all samples, the lysis solutions were disrupted using FastPrep FP 120 (Bio 101 Thermo Electron Corporation, Milford, USA) at $5 \mathrm{~m} / \mathrm{s}$ for $20 \mathrm{~s}$. DNA was finally

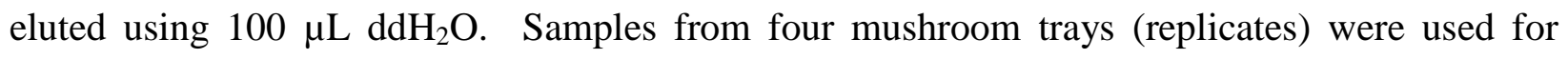
molecular analysis.

\section{PCR amplification}

Enzymatic amplification of the $16 \mathrm{~S}$ rDNA region was performed using the primers Prun518r 5'ATT-ACC-GCG-GCT-GCT-GG3' and PA8f-GC 5'CGC-CCG-CCG-CGC-GCG-GCG-GGCGGG-GCG-GGG-GCA-CGG-GGG-GAG-AGT-TTG-ATC-CTG-GCT-CAG3， designed for DGGE by Øvereås et al. (1997) and Fjellbirkeland et al. (2001) respectively. The reaction consisted of a total volume of $25 \mu \mathrm{L}$ containing the following reagents: $19.25 \mu \mathrm{L}$ double sterilised distilled water, $2.5 \mu \mathrm{L}$ PCR buffer, $1 \mu \mathrm{L} \mathrm{MgCl}_{2}(10 \mathrm{x}), 1 \mu \mathrm{L}$ dNTPs $(2.5 \mu \mathrm{mol} / \mathrm{L}), 0.25$ $\mu \mathrm{L}$ of each primer (10 pmol/L), $0.25 \mu \mathrm{L} \mathrm{Taq}$ DNA polymerase (5 units/ $\mu \mathrm{L})$ and $0.5 \mu \mathrm{L}(\sim 25$ $\mathrm{ng} / \mu \mathrm{L}$ ) of sample DNA. PCR amplification was performed in an Eppendorf (Merck) thermal cycler starting with $10 \mathrm{~min}$ denaturation at $95{ }^{\circ} \mathrm{C}$ followed by 35 cycles of 30 s denaturation at 94 ${ }^{\circ} \mathrm{C}, 30 \mathrm{~s}$ annealing at $58{ }^{\circ} \mathrm{C}, 1 \mathrm{~min}$ extension at $72{ }^{\circ} \mathrm{C}$, and a final $10 \mathrm{~min}$ extension at $72{ }^{\circ} \mathrm{C}$. Fungal and yeast DNA was amplified using the primers ITS3 (5'-CGC-CCG-CCG-CGC-GCGGCG-GGC-GGG-GCG-GGG-GCA-CGG-GGG-GCA-TCG-ATG-AAG-AAC-GCA-GC-3') and ITS4 (5'-TCC-TCC-GCT-TAT-TGA-TAT-GC-3') (White et al. 1990). PCR was performed as 
above for bacteria except that the annealing temperature was lowered to $55^{\circ} \mathrm{C}$. The amplicons were visualized on a $1 \%$ agarose gel stained with $0.01 \%$ ethidium bromide in a Vilber Lourmat (Omni-Science CC, South Africa) gel imaging system.

\section{Denaturing gradient gel electrophoresis (DGGE)}

DGGE was performed using a D-Code (BIO-Rad, South Africa) universal mutation detection system. PCR products of $10 \mu \mathrm{L}$, each mixed with $3 \mu \mathrm{L}$ loading dye were loaded onto $40-55 \%$ and 30-60 denaturing gradient polyacrylamide (40\%) gels for bacterial and fungal (or yeast) DNA respectively. Electrophoresis was performed at $20 \mathrm{~V}$ for $10 \mathrm{~min}$ to allow gels to acclimatise and then at $70 \mathrm{~V}$ at a temperature of $60{ }^{\circ} \mathrm{C}$ for $17 \mathrm{~h}$. The gels were then stained with $4 \mu \mathrm{L}$ SYBR Gold nucleic acid gel stain (Whitehead Scientific, South Africa) for one hour in the dark, then visualized and photographed under UV light in a Vilber Lourmat gel imaging system.

\section{Band excision, purification and sequencing}

Dominant bands from the resulting fingerprint pattern on the gels were excised under blue light on a Jiffy Lites Blue Light Box (Inqaba Biotec) using a clean scalpel. The excised acrylamide gel fragments containing the bands were placed in sterile $1.5 \mathrm{~mL}$ micro tubes, each containing 30 $\mu \mathrm{L}$ of sterile double distilled water and stored at $4{ }^{\circ} \mathrm{C}$ for at least $24 \mathrm{~h} . \mathrm{A} 0.5 \mu \mathrm{L}$ aliquot of the liquid was then used as a template for re-amplification using the previously mentioned primers. The DNA yield was verified by visualizing the amplicon on $1 \%$ agarose gel as mentioned previously.

PCR products were purified with a PCR Purification Kit (250) (QIAquick, South Africa) according to manufacturer instructions and sequenced at the University of Pretoria's sequencing 
unit. Sequences and electropherograms were edited using Chromas (Chromas Lite 2.01, 19982005 Technelysium (Pty.) Ltd.) available online at http//www.technelysium.com.au/chromas_lite.html.

\section{Phylogenetic analysis}

A BLAST search was done for each sequence on the GenBank database and matching hits, with the highest percentage identity and e-values closest to 0.0 indicating a statistically acceptable match, were selected for alignment. Resulting sequences were edited using Contig express (Vector NTI advance 11.0, Invitrogen 2008) and aligned with Clustal X; inserted gaps were treated as missing data. Analysis for phylogenetic relationships was performed based on parsimony using PAUP 4.0b8 (Phylogenetic Analysis Using Parsimony). Random addition of sequences (100 replicates), tree bisection-reconnection, branch swapping, MULPAR-effective and MaxTrees were used to perform Heuristic searches. Tree length distributions over 100 randomly generated trees were evaluated to assess phylogenetic signals in the data sets. The consistency (CI) and retention indices (RI) were determined for all data sets. Phylogenetic trees were rooted with Nitrospira sp., Agaricus bisporus, and Dipodascus capitatus as outgroups to the remaining taxa of bacteria, fungi and yeasts respectively. In order to determine confidence in the branching points (1000 replicates), bootstrap values were generated retaining groups with greater than $70 \%$ consistency. Bacterial and yeast nucleotide sequences have been deposited in GenBank database under the accession numbers JX542612 and JX573203-JX573298. Fungal nucleotide sequences are available in Online Resource 1. 


\section{Taxonomic classification}

Sequence identity threshold using 16S (bacteria) and 18S (fungi and yeast) rDNA sequence was set at a similarity of $\geq 99 \%$ for species level and $\geq 97 \%$ for genus level with reference to GenBank prototype strain sequences (Drancourt et al. 2000; Orgiazzi et al. 2013). Sequences having similarity score of rDNA lower than $97 \%$ as compared to those deposited in GenBank at the time of analysis were classified only at ranks higher than genus (Everett, et al. 1999).

\section{Statistical analysis}

Data distributions of bacterial, fungal and yeast counts were tested for normality using SPSS, Version 20.0 (IBM Corp) with Shapiro-Wilk Test at an alpha level of 0.05. All bacterial data sets were normally distributed. Therefore, bacterial counts of samples of all groups were compared by performing general analysis of variance (ANOVA) using GenStat release 7.22 DE, 2009 (GenStat Discovery Edition 3). For fungal and yeast counts, few groups (two out of seven and one out of seven for fungal and yeast counts respectively) were non-normal distribution. Consequently, a non-parametric method - Kruskal-Walis test was conducted using SPSS on fungal and yeast data sets in cases of non-normal distributions. Significant difference between groups was considered at $\mathrm{P}<0.05$ and alpha level of 0.05 . Unless referred as median, all data presentations were mean values. Mean values were used to compare differences between groups of normal distribution while median values were used to compare groups of non-normal distribution. Data sets of non-normal distribution were not included in bar graphs. 

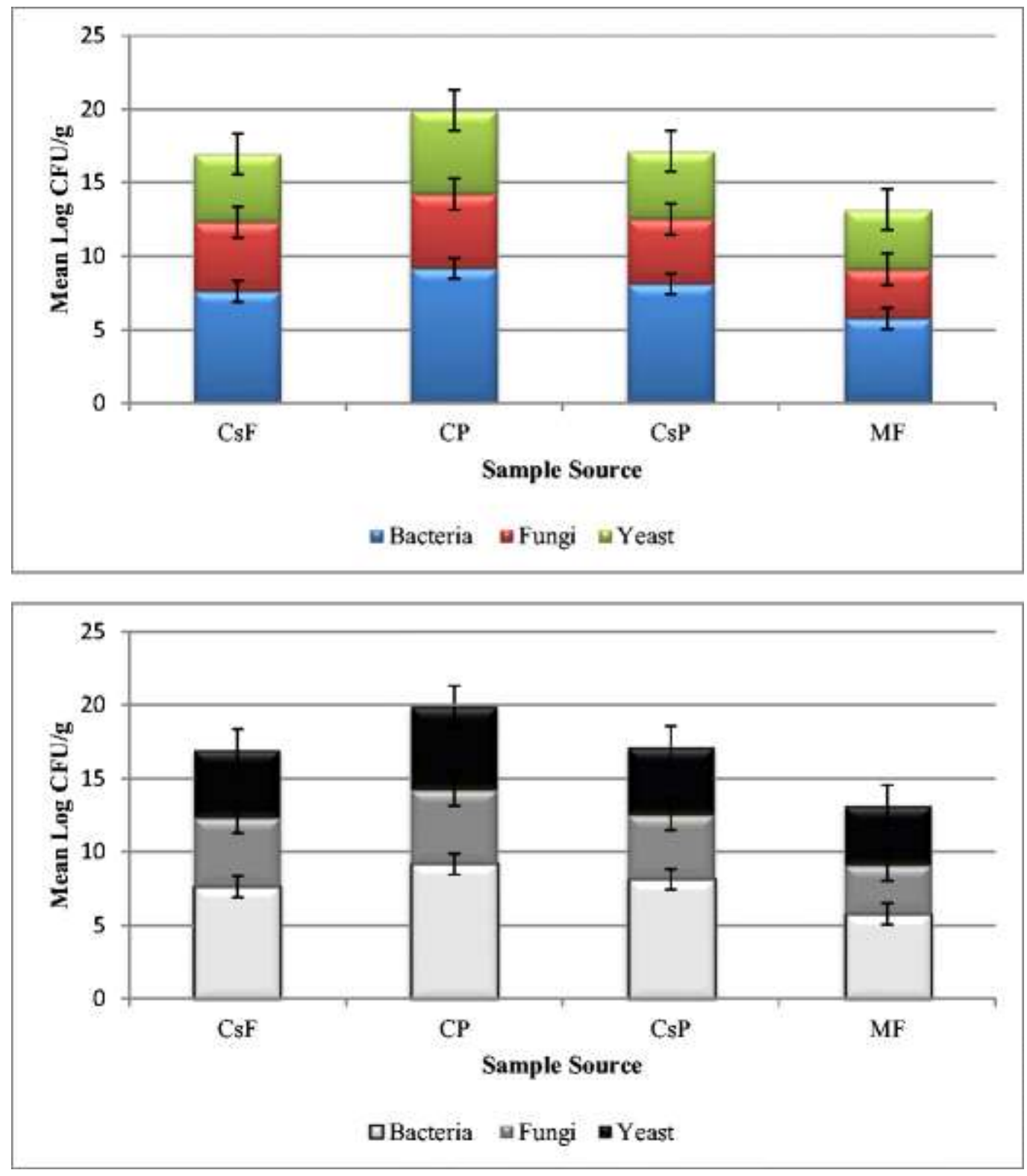

Fig 2 Total mean microbial populations in compost, casing and on mushrooms at harvest (CP compost; $\mathrm{CsF}$ casing fresh; CsP casing at pinning; MF mushrooms fresh) 


\section{Results}

\section{Microbial populations on compost, casing and fresh mushrooms}

Total bacterial counts were significantly higher for compost samples than for casing and mushroom samples (Fig 2). Fresh casing had a lower count than casing at pinning. Least bacteria were found on the fresh mushrooms (log CFU/g 5.8). The fungal colony counts were lower than those for bacteria and yeasts in all samples. Fungal colony counts were significantly higher for compost (CP) samples (log CFU/g 5.0) than for casing (CsF and CsP) and fresh mushroom samples (Fig 2).

Total colony counts of yeasts were significantly higher for compost than for casing and fresh mushroom samples (Fig 2). Compost had the highest yeast count (mean $\log$ CFU/g 5.68) followed by $\log \mathrm{CFU} / \mathrm{g} 4.63$ in fresh casing and $\log \mathrm{CFU} / \mathrm{g} 4.62$ in casing at pinning. It was interesting to note that the total yeast counts of the two subsamples (data not shown) showed a significant difference.

\section{Microbial populations on postharvest mushroom samples, during storage and retail}

There was a significant increase of bacterial and yeast colony counts on mushrooms from picking to twelve days of storage (Fig 3). Least bacteria were found on the fresh mushrooms ( $\log$ CFU/g 5.8), after which it increased to $\log$ CFU/g 7.6 on day 12. Fungal counts on freshly picked samples were also higher (MF; log CFU/g 3.3) than those after day four (M4; log CFU/g 2.8) (Fig 3). Both the bacterial and the yeast counts increased from freshly picked to day 12 , while that of fungi remained the same although a slight decrease was observed on day four (Fig 
3). The average over 12 days was $\log \mathrm{CFU} / \mathrm{g} 7.6$ (mean) for bacteria, log CFU/g 6.33 (median) for yeasts and $\log \mathrm{CFU} / \mathrm{g} 2.8$ (median) for fungi.
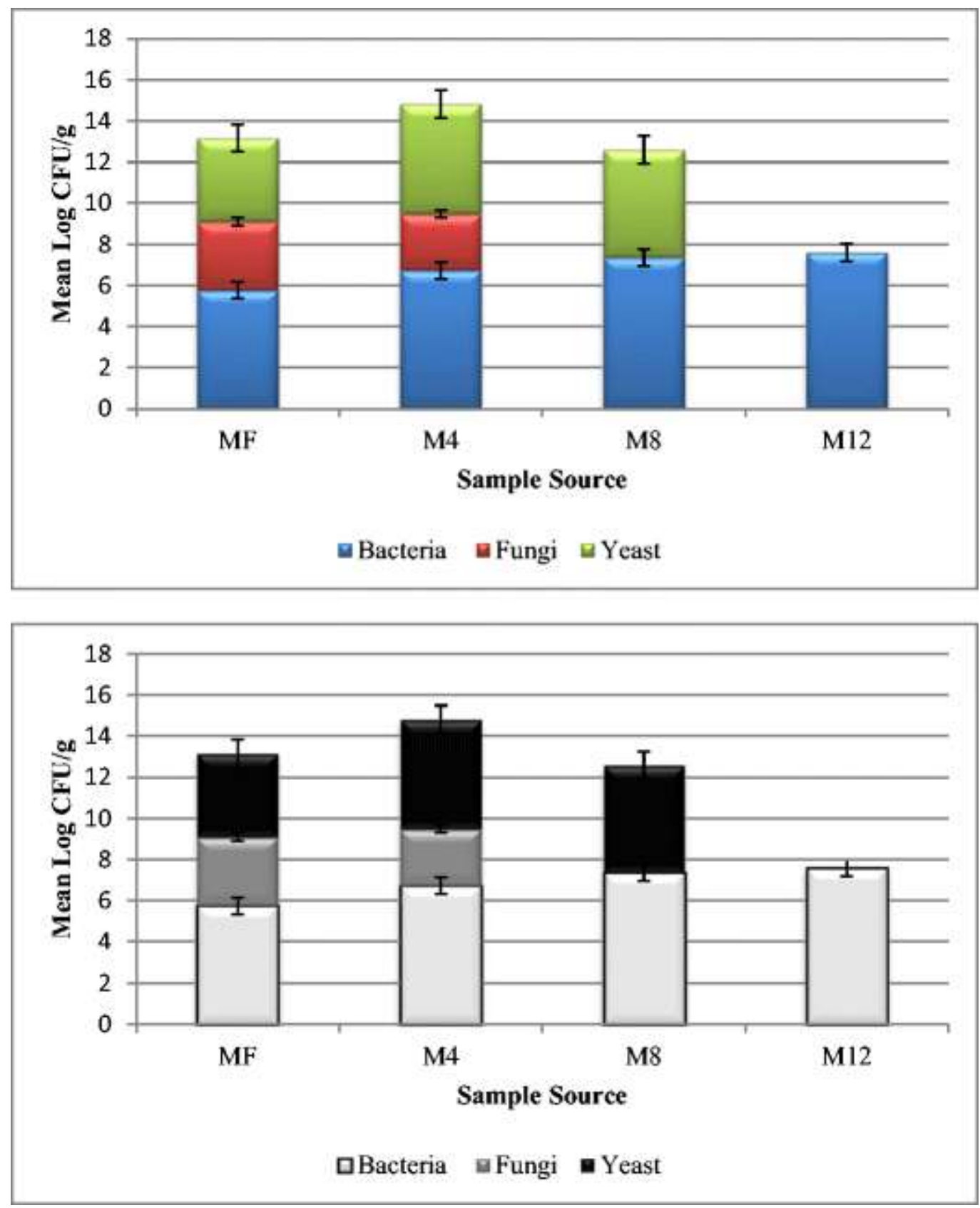

Fig 3 Total mean microbial populations on mushrooms from harvest to 12 days after picking (MF mushrooms fresh; M4 mushrooms day 4; M8 mushrooms day 8; M12 mushrooms day 12) 


\section{Pure culture identification using sequencing}

Across board, the culturable bacteria of compost samples showed less diverse phyla than those of casing and mushroom samples. Bacteria in casing samples were more diverse than those in mushroom samples. Bacteria isolated from compost samples were members of two phyla, Actinobacteria and Proteobacteria while those from casing samples were members of four phyla, Actinobacteria, Proteobacteria, Firmicutes, and Bacteroidetes. Bacteria from mushroom samples were members of the three phyla, Actinobacteria, Proteobacteria, and Bacteroidetes. In all compost, casing and mushroom samples, the phylum Proteobacteria was the most prevalent (Table 1). All fungal cultures isolated belonged to the phylum Ascomycota and the three classes Pezizomycetes, Sordariomycetes and Eurotiomycetes. From the class Eurotiomycetes, the genus Penicillium of the family Trichocomaceae was prevalent in compost, casing and mushroom samples (Table 2). More detailed BLAST results of bacterial and fungal nucleotide sequences are shown in Online Resource 2.

All bacterial DNA sequences of dominant DGGE gel bands matched with four phyla, viz. Bacteroidetes, Firmicutes, Actinobacteria and Proteobacteria. Members of the first three phyla were extracted predominantly from compost samples while the last phylum, Proteobacteria originated mostly from casing and mushroom samples. Of the three classes in this phylum namely Betaproteobacteria, Alphaproteobacteria and Gammaproteobacteria, the latter was the most prevalent. The genus Pseudomonas of the family Pseudomonadaceae and order Pseudomonadales was the most dominant in mushroom samples (Table 3). 
Table 1 Identification of bacteria isolated from compost, casing and mushrooms using DNA sequencing and tentative BLAST

\begin{tabular}{|c|c|c|c|c|c|c|c|}
\hline \multirow{2}{*}{$\begin{array}{l}\text { Sour } \\
\text { ce }\end{array}$} & \multicolumn{7}{|c|}{ Closest relatives } \\
\hline & Phylum & Class & Order & Family & Genus & Species & $\begin{array}{l}\text { Accession } \\
\text { no. }\end{array}$ \\
\hline \multirow{5}{*}{$\begin{array}{l}\overrightarrow{\tilde{o}} \\
\stackrel{0}{\Xi} \\
\text { ¿े }\end{array}$} & $\begin{array}{l}\text { Actinoba } \\
\text { cteria }\end{array}$ & Actinobacteria & Actinomycetales & Micrococcaceae & Arthrobacter & arilaitensis* & GU220063 \\
\hline & $\begin{array}{l}\text { Proteoba } \\
\text { cteria }\end{array}$ & $\begin{array}{l}\text { Gammaproteobacter } \\
\text { ia }\end{array}$ & Enterobacteriales & Enterobacteriaceae & Enterobacter & sp.* & JF772582 \\
\hline & & & & & Citrobacter & koseri* & EF059858 \\
\hline & & & & & Serratia & marcescens* & EU302853 \\
\hline & & & Pseudomonadales & Pseudomonadaceae & Pseudomonas & putida* & EU931564 \\
\hline \multirow{14}{*}{. } & Proteoba & Betaproteobacteria & Burkholderiales & Comamonadaceae & Acidovorax & temperans* & AM286541 \\
\hline & & Alphaproteobacteria & Rhodobacterales & Rhodobacteraceae & Paracoccus & koreensis* & NR_041238 \\
\hline & & & Rhizobiales & Bradyrhizobiaceae & Bosea & thiooxidans* & EU7̄30912 \\
\hline & & & & Rhizobiaceae & Shinella** & kummerowiae & NR_044066 \\
\hline & & & & Hyphomicrobiaceae & Devosia** & hwasunensis & AM393883 \\
\hline & & & & Phyllobacteriaceae & Aminobacter ${ }^{* *}$ & sp. & AB480343 \\
\hline & & & & Rhizobiaceae & Rhizobium** & sp. & AM084044 \\
\hline & & & & Phyllobacteriaceae & Pseudaminobacter** & salicylatoxidans & AJ294416 \\
\hline & & & & & Mesorhizobium & sp.* & HQ540554 \\
\hline & $\begin{array}{l}\text { Firmicut } \\
\text { es }\end{array}$ & Bacilli & Lactobacillales & Carnobacteriaceae & Trichococcus** & collinsii & EF111215 \\
\hline & $\begin{array}{l}\text { Bacteroi } \\
\text { detes }\end{array}$ & Sphingobacteria & Sphingobacteriales & Chitinophagaceae & Terrimonas** & sp. & JN848793 \\
\hline & & & & Sphingobacteriaceae & Sphingobacterium $* *$ & sp. & EF059711 \\
\hline & Actinoba & Actinobacteria & Actinomycetales & Nocardiaceae & Rhodococcus ${ }^{* *}$ & sp. & EU878273 \\
\hline & & & & Microbacteriaceae & Microbacterium & sp.* & EU821337 \\
\hline
\end{tabular}


Table 1 (Continued)

\begin{tabular}{|c|c|c|c|c|c|c|c|}
\hline \multirow[t]{2}{*}{ Source } & \multicolumn{7}{|l|}{ Closest relatives } \\
\hline & Phylum & Class & Order & Family & Genus & Species & $\begin{array}{l}\text { Accession } \\
\text { no. }\end{array}$ \\
\hline \multirow{6}{*}{ 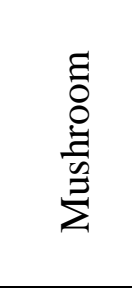 } & Bacteroidetes & Sphingobacteriia & Sphingobacteriales & Sphingobacteriaceae & Sphingobacterium & multivorum* & HM355636 \\
\hline & Actinobacteria & Actinobacteria & Actinomycetales & Microbacteriaceae & Microbacterium $^{* *}$ & foliorum & JF303045 \\
\hline & Proteobacteria & Betaproteobacteria & Burkholderiales & Alcaligenaceae & Alcaligenes & faecalis* & FJ959394 \\
\hline & & Gammaproteobacteria & Pseudomonadales & Pseudomonadaceae & Pseudomonas & Putida* & JN228297 \\
\hline & & & & & & fluorescens & EF602564 \\
\hline & & & Enterobacteriales & Enterobacteriaceae & Ewingella & americana* $^{*}$ & HE585223 \\
\hline
\end{tabular}

(Identification: * at species level, ** at genus level) 
Table 2 Identification of fungi and yeasts isolated from compost, casing and mushrooms using DNA sequencing and tentative BLAST (' $\mathrm{C}$ ' represents compost, 'Cs' represents casing and ' $\mathrm{M}$ ' represents mushroom)

\begin{tabular}{|c|c|c|c|c|c|c|c|c|}
\hline \multirow{2}{*}{\multicolumn{2}{|c|}{ Source }} & \multirow{2}{*}{\multicolumn{7}{|c|}{ Closest relatives }} \\
\hline & & & & & & & & \\
\hline \multirow{11}{*}{ 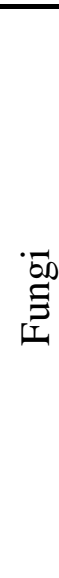 } & Cs & Ascomycota & Pezizomycetes & Pezizales & Pezizaceae & Chromelosporium & & EF589890 \\
\hline & $\mathrm{Cs}$ & & Sordariomycetes & Hypocreales & Bionectriaceae & Bionectria & sp. & AM944351 \\
\hline & $\mathrm{Cs}$ & & & Microascales & Microascaceae & Pseudallescheria** & boydii & GU566282 \\
\hline & $\mathrm{Cs}$ & & & Sordariales & Chaetomiaceae & Chaetomium & sp. & AB506801 \\
\hline & $\mathrm{Cs}$ & & & Hypocreales & Hypocreaceae & Trichoderma** & sp. & AY514867 \\
\hline & $\mathrm{M}$ & & Eurotiomycetes & Eurotiales & Trichocomaceae & Paecilomyces** & sinensis & FJ904847 \\
\hline & $\mathrm{M}, \mathrm{Cs}$ & & & & & Penicillium & madriti $^{*}$ & AF033482 \\
\hline & $\mathrm{C}, \mathrm{Cs}, \mathrm{M}$ & & & & & Penicillium $^{* *}$ & chrysogenum & GU565114 \\
\hline & $\mathrm{C}, \mathrm{Cs}$ & & & & & Penicillium $^{* *}$ & ochrochloron & JF311909 \\
\hline & $\mathrm{M}$ & & & & & Penicillium** & meleagrinum & HM469412 \\
\hline & $\mathrm{M}, \mathrm{Cs}$ & & & & & Penicillium & $\begin{array}{l}\text { brevicompactum } \\
*\end{array}$ & HM469408 \\
\hline \multirow{9}{*}{$\overrightarrow{\tilde{E}}$} & C,M & $\begin{array}{l}\text { Basidiomyc } \\
\text { ota }\end{array}$ & Tremellomycetes & $\begin{array}{l}\text { Cystofilobasidial } \\
\text { es }\end{array}$ & Cystofilobasidiaceae & Cystofilobasidium & $\begin{array}{l}\text { infirmominiat } \\
\text { um* }^{*}\end{array}$ & AY264716 \\
\hline & $\mathrm{C}, \mathrm{M}$ & & Urediniomycetes & Sporidiobolales & Sporidiobolaceae & Rhodotorula & $\begin{array}{l}\text { mucilaginosa } \\
*\end{array}$ & EF174513 \\
\hline & $\mathrm{C}$ & & Tremellomycetes & Tremellales & Trichosporonaceae & Trichosporon & moniliiforme* & FR799471 \\
\hline & $\mathrm{C}$ & & & & & Trichosporon & cutaneum* $^{*}$ & FJ943422 \\
\hline & $\mathrm{C}$ & Ascomycota & Saccharomycetes & $\begin{array}{l}\text { Saccharomycetal } \\
\text { es }\end{array}$ & Saccharomycetaceae & Candida & glaebosa* & FJ153208 \\
\hline & $\mathrm{Cs}$ & & & & & Candida & subhashii & EU836707 \\
\hline & $\mathrm{Cs}$ & & & & & Candida & sp. & HQ623537 \\
\hline & Cs & & & & & Candida & sp. & JF895510 \\
\hline & $\mathrm{Cs}$ & & & & & Pichia & sp. & FJ153190 \\
\hline
\end{tabular}

(Identification: $*$ at species level, $* *$ at genus level) 
Table 3 Identification of bacteria from dominant DGGE bands by sequencing DNA derived from compost, casing and mushroom samples ('C' represents compost, 'Cs' represents casing and ' $\mathrm{M}$ ' represents mushroom) and tentative BLAST

\begin{tabular}{|c|c|c|c|c|c|c|c|}
\hline \multirow[t]{2}{*}{ Source } & \multicolumn{7}{|c|}{ Closest relatives } \\
\hline & Phylum & Class & Order & Family & Genus & Species & Accession no. \\
\hline $\bar{C}$ & $\begin{array}{l}\text { Bacteroi } \\
\text { detes }\end{array}$ & Sphingobacteriia & Sphingobacteriales & Chitinophagaceae & Flavisolibacter & sp. & HM130561 \\
\hline $\mathrm{C}$ & $\begin{array}{l}\text { Bacteroi } \\
\text { detes }\end{array}$ & Bacteroidetes Order II & Incertaesedis & Rhodothermaceae & Rhodothermus & obamensis & AF217493 \\
\hline $\mathrm{C}$ & $\begin{array}{l}\text { Firmicut } \\
\text { es }\end{array}$ & Bacilli & Bacillales & Bacillaceae & Bacillus & badius & JN624927 \\
\hline $\mathrm{C}$ & & & & Cellulomonadaceae & Cellulomonas & sp. & JN181251 \\
\hline $\mathrm{C}$ & & & & Streptosporangiaceae & Microbispora & sp. & AF131381 \\
\hline $\mathrm{M}, \mathrm{C}$ & & & & Geodermatophilaceae & Blastococcus & sp.* & AB540018 \\
\hline $\mathrm{C}$ & $\begin{array}{l}\text { Proteoba } \\
\text { cteria }\end{array}$ & Betaproteobacteria & Burkholderiales & Alcaligenaceae & Bordetella & sp. & AB039335 \\
\hline Cs & & & & Comamonadaceae & Curvibacter & sp. & HM357758 \\
\hline Cs & & Alphaproteobacteria & Rhizobiales & Phyllobacteriaceae & Chelativorans & $\begin{array}{l}\text { multitrophic } \\
\text { us }\end{array}$ & FJ167676 \\
\hline Cs & & & & Rhizobiaceae; & Rhizobium** $^{* *}$ & sp. & DQ303370 \\
\hline Cs & & & & Rhizobiaceae & Shinella** & sp. & GQ246688 \\
\hline Cs & & & Sphingomonadales & Sphingomonadaceae & Sphingomonas** & sp. & AJ009709 \\
\hline M & & & & & & sp.* & HQ331138 \\
\hline Cs & & & & & Novosphingobium & $\begin{array}{l}\text { panipatense } \\
*\end{array}$ & JF459982 \\
\hline $\mathrm{C}$ & & Gammaproteobacteria & Xanthomonadales & Xanthomonadaceae & Luteimonas & sp. & AM932272 \\
\hline M & & & Enterobacteriales & Enterobacteriaceae & Ewingella & americana* & HE585223 \\
\hline $\mathrm{C}$ & & & Pseudomonadales & Pseudomonadaceae & Pseudomonas & sp. & FM161512 \\
\hline M & & & & & Pseudomonas & sp.* & AF408925 \\
\hline M & & & & & Pseudomonas** & sp. & HQ224640 \\
\hline M & & & & & Pseudomonas & sp.* & JF694807 \\
\hline M & & & & & Pseudomonas & $\begin{array}{l}\text { fluorescens } \\
*\end{array}$ & HQ832772 \\
\hline
\end{tabular}


Page 19 of 38

\begin{tabular}{|c|c|c|c|}
\hline $\bar{M}$ & Pseudomonas & syringae & JN088486 \\
\hline M & Pseudomonas & migulae* & DQ377758 \\
\hline $\mathrm{M}, \mathrm{Cs}$ & Pseudomonas & $\begin{array}{l}\text { Plecoglossi } \\
\text { cida* }^{*}\end{array}$ & JN624752 \\
\hline $\mathrm{M}, \mathrm{Cs}$ & Pseudomonas & putida* & AF396076 \\
\hline $\mathrm{M}, \mathrm{Cs}$ & Pseudomonas & reactans* & JN662499 \\
\hline $\mathrm{M}, \mathrm{Cs}$ & Pseudomonas & $\begin{array}{l}\text { nitroreduce } \\
\text { ns }\end{array}$ & JF513151 \\
\hline
\end{tabular}

(Identification: $*$ at species level, $* *$ at genus level) 


\section{Microbial profile of compost, casing and mushroom samples on DGGE}

The compost, casing and mushroom samples displayed distinct bacterial profiles (Fig 4). Banding patterns depicted more diverse bacterial species in compost samples than in casing and mushroom samples. The bands also depicted that the bacterial profile of mushrooms had greater similarity to that of the casing than to the compost. Mushroom samples had relatively less diverse but abundant bacterial species than those of the casing and the compost samples.

The DGGE gel of amplified fungal and yeast DNA showed a uniform pattern for compost, casing at pinning and both mushroom (fresh and eight days stored) samples (Fig 4). All these samples were completely dominated by A. bisporus itself. Only the casing samples depicted some yeast and other fungal species (data not shown).

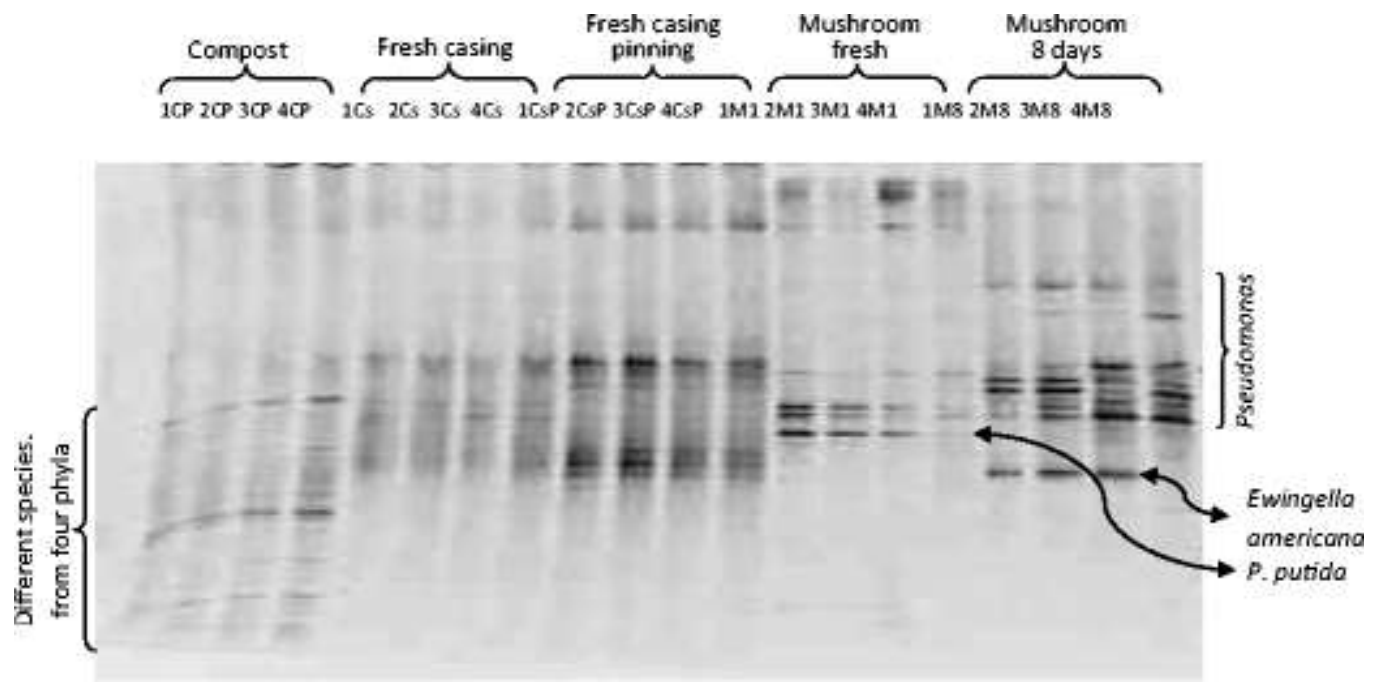

Fig 4 Denaturing gradient gel electrophoresis images of amplified bacterial DNA derived from compost (CP), casing fresh (Cs) and casing at pinning (CsP) and mushrooms fresh (M) and after eight days of storage at $4^{\circ} \mathrm{C}(\mathrm{M} 8)$ 


\section{Phylogenetic relationships of cultured and non-cultured microorganisms from compost, casing and mushrooms}

Bacteria from mushrooms showed phylogenetic relationships with those from both casing and compost (Fig 5). The first four big clades of the phylogenetic tree consisted of bacteria from all three sources (compost, casing and mushroom). Generally, bacterial sequences from both cultures and from amplified DNA of DGGE gel bands grouped together in the different clusters (clades 1-4). However, four separate clades (clades 5, 6, 8, and 9) of amplified DNA from DGGE gel bands were formed. In the cluster (clade 3) which consisted of different Pseudomonas species, the majority of its members originated from mushroom samples, specifically from amplified DNA of the DGGE gel bands.

Almost all DNA sequences of yeasts and fungi were derived from pure culture isolates, since fungal (and yeast) DGGE profiles of samples were dominated by the A. bisporus itself. Penicillium spp. were commonly isolated from compost, casing and mushroom samples. The phylogenetic tree of yeasts formed two clades (Fig 6). Clade 1 consisted of sequences predominantly from compost and mushrooms while clade 2 contained sequences from casing except for one from compost. 

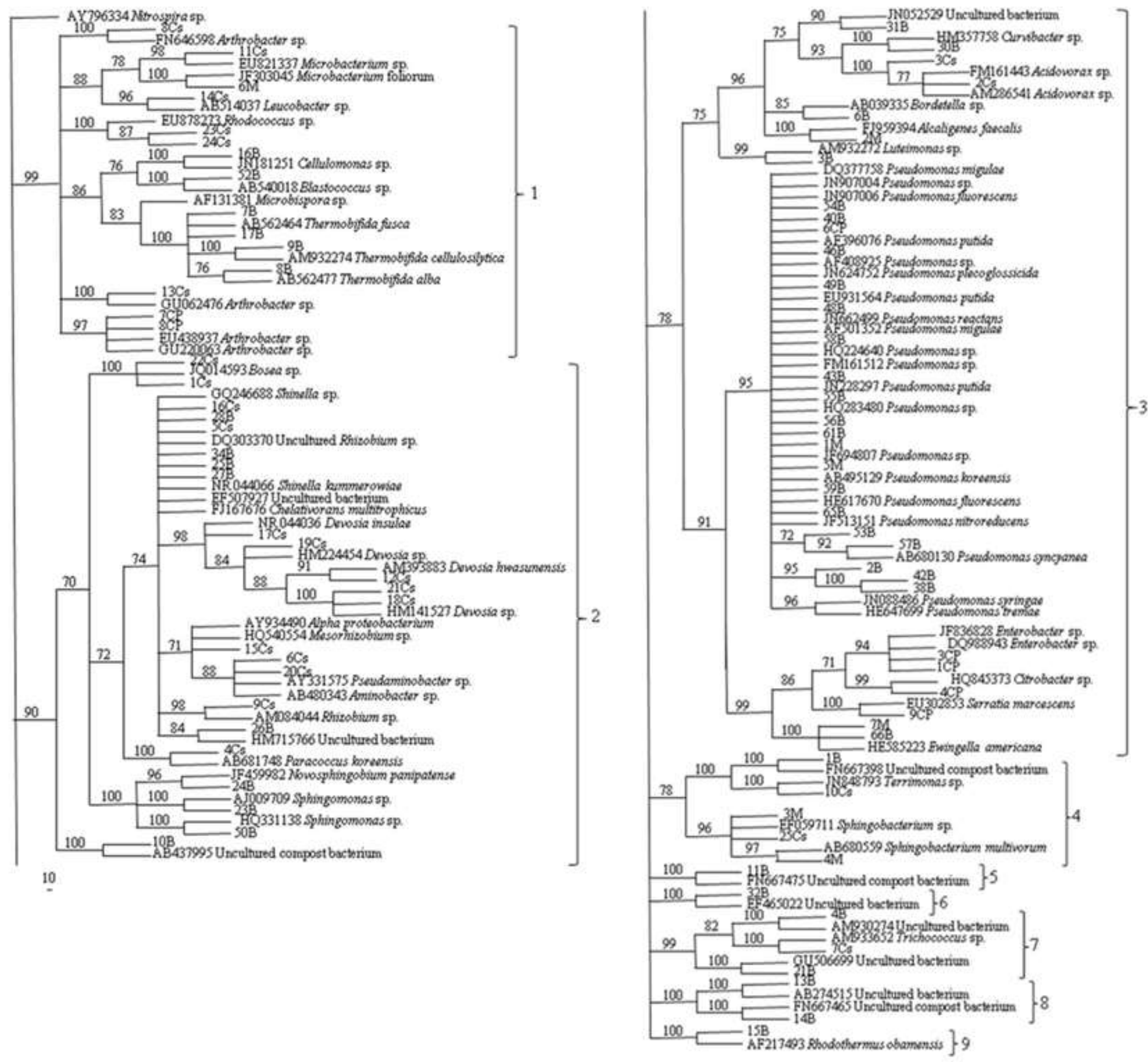

10

Fig 5 Rooted phylogenetic tree based on parsimony showing phylogenetic relationships of bacteria derived from compost, casing, mushroom samples and most closely related matching sequences obtained from BLAST searches. Sequences of isolates from compost, casing and mushrooms are suffixed by 'CP', 'Cs' and ' $\mathrm{M}$ ' respectively. Sequences from amplified DNA of DGGE bands are represented by a number and the letter 'B' [Parsimony informative characters are $450, \mathrm{CI}=0.3260, \mathrm{RI}=0.7923$, number of trees $=100$, tree length $=765.56992$ and $\mathrm{gl}=-$ 


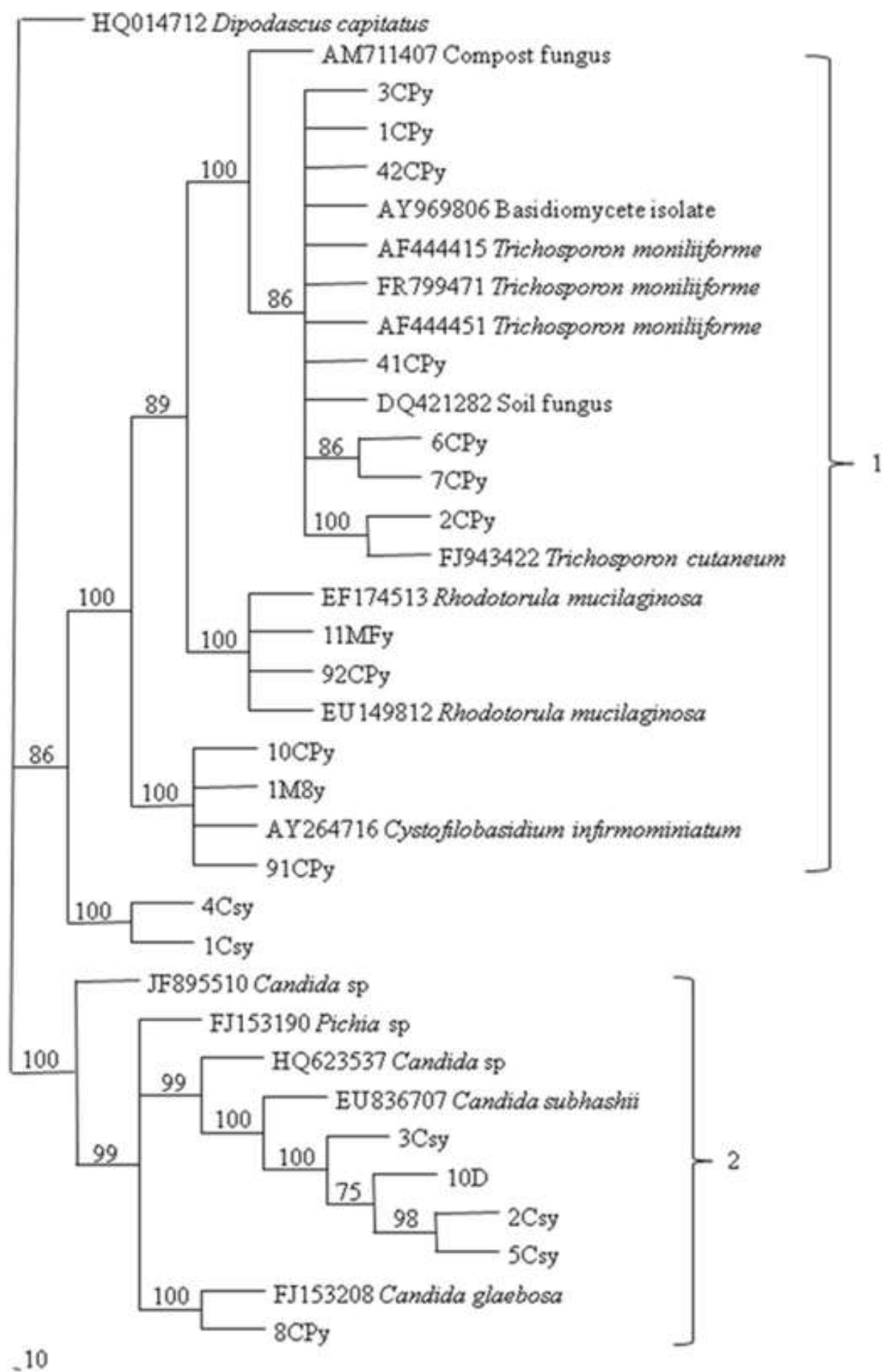

Fig 6 Rooted phylogenetic tree based on ITS region sequences of yeasts derived from compost, casing and mushroom samples and most closely related sequences obtained from BLAST searches. Sequences from compost, casing and mushrooms are suffixed by 'CPy', 'Csy' and 'My' respectively [Parsimony informative characters are $270, \mathrm{CI}=0.7495, \mathrm{RI}=0.9337$, number of trees $=100$, tree length $=470.22827$ and $\mathrm{g} 1=-0.379514]$ 


\section{Discussion}

Most of the microbiological studies on compost and composting were either not specific on materials for mushroom growing, or if so, they were on the phases before spawning. Few studies were done on spawned mushroom compost, however, information on diversity was not provided. Fordyce (1970) reported mesophilic bacteria in the order of $10^{6}-10^{7} / \mathrm{g}$ for a three week spawned compost. Fermor and Wood (1981) also mentioned a reduction and stabilisation of bacterial numbers in spawned compost following the high number and activity of bacteria in Phase I and II compost. On both studies, there was no report on diversity. This study therefore provides baseline microbial population information on mushrooms, compost and casing material and the resultant mushroom fruit body growth during the production cycle and resultant shelf-life after picking, packing and cold storage till marketing.

Although compost is known as a nutrient rich medium, bacterial populations at the end of Phase II composting stage create unfavourable conditions for competitive microorganisms and provide selectivity to A. bisporus (Fordyce, 1970; Ross and Harris, 1983). Phase II composting involves conditioning, which is a controlled heat treatment that selectively kills pathogenic micro-organisms. Other non-pathogenic bacteria may remain static at this stage of composting and become active later when the temperature is lowered. This trend was confirmed in our study when comparing the compost casing and mushroom microbial profiles. Bacterial populations of compost were significantly higher than those of the casing and mushroom samples.

In general, the plating method used demonstrated richer microbial population counts in compost samples compared with casing and mushroom samples. It was interesting to note the significant difference in total yeast colony counts between the compost subsamples. This 
suggested that yeast populations are influenced by homogeneity of samples more than bacteria. Considering the lack of information on the identity and role of yeasts, more studies in this regard should be undertaken.

The casing layer in this study was prepared from peat, which is naturally formed from partially decomposed plant material. Unlike compost, peat is relatively poor in nutrients and decomposed organic matter (Eakin, 1969; Abad et al. 1989). Therefore, it is not unexpected that total bacterial colony count was significantly lower in the casing compared to the compost. Even so, total bacterial colony counts in casing increased significantly at pinning; although this count was still significantly lower than that of the compost. This significant increase in total bacterial counts from casing to pinning is consistent with previous work (Miller et al. 1995; Siyoum et al. 2010). In the cultivation of $A$. bisporus, compost and casing soil are two major elements; studies have also demonstrated that populations of pseudomonas in the casing layer on which the mushroom fruit body develops play an important role (Riahi et al. 2011). In most studies, total bacterial populations ranged from $\log \mathrm{CFU} / \mathrm{g} 8.0$ to 8.5 casing material and the majority of bacterial populations in casing were attributed to pseudomonas species. According to Riahi et al. (2011) pseudomonads represented more than 80 percent of the bacterial population in the casing layer. Their results also showed that there was a close relation between growth of mycelium and number of bacteria in casing soil. Sampling of casing soil at different stages of the mushroom growing cycle further revealed that the number of bacteria increased simultaneously with increased growth of mycelium into the casing soil. Riahi et al. (2011) concluded that the inoculation of native $P$. putida isolated from casing soil at the primordia formation stage would be very efficient for increasing mushroom yield and quality. 
Fresh casing samples had lower total colony counts of fungi than in compost samples although the difference was not initially significant. However, at pinning, the total fungal colony count of the casing was reduced to a significantly lower level than that of the compost. Verhoeven (1986) described that fungi do not have a significant role to play in peat, unlike bacteria. Like bacteria and fungi, yeast populations were also significantly higher in compost samples than in the casing and fresh mushroom samples. The overall lower microbial counts in casing compared to compost may be attributed to limited energy sources and lack of available nutrients in peat soil according to Verhoeven (1986).

In our study, there also was a significant increase in total bacteria and yeasts on mushrooms from the time of harvest to twelve days after cold storage while fungi remained constant. A similar trend for bacteria, yeasts and moulds was also reported by Chikthimmah (2006). Postharvest spoilage of mushrooms caused by bacteria is well established (Burton and Noble, 1993; Fett et al. 1995; Wells et al. 1996). However, the role of yeasts in mushroom spoilage was not investigated in this study and needs further investigation.

Bacteria isolated from compost were less diverse at phylum and family level than those isolated from casing and mushrooms. Compost bacteria belonged to two phyla and three families only while casing bacteria belonged to four phyla and eleven families. The extent of diversity within bacteria isolated from mushrooms lies between that of the two substrates. Cultured bacteria of mushrooms belonged to three phyla and five families. Visual examination of bacterial plates illustrated more uniform colonies for compost and mushroom than for casing samples, which could be attributed to the less diverse families. Our low diversity result of culturable compost bacteria is in agreement with Peters et al. (2000) although they investigated 
only the thermophilic group. However, work by Ryckeboer et al. (2003b) is not consistent with our result. The reason for this could be the difference in the type of the compost material (vegetable, fruit and garden waste in their case).

Results from our DGGE analysis provided a different profile of bacterial diversity in the compost, casing and mushrooms. Bacterial diversity was highest in compost samples. DNA sequences that were closely related to known cultured species belonged to four phyla for compost samples but only to one and two phyla for casing and fresh mushroom samples respectively. The difference in diversity results between the culturing and the DGGE methods is understandable. It is known that bacteria that grow in an artificial medium represent only a small fraction $(0.3 \%$ in soil habitat $)$ of the total community in the sampled environment (Amann et al. 1995). Therefore, isolates obtained using culturing methods might not necessarily be the dominant ones in their habitat. Several researchers have reported that some cultured bacteria were not part of the dominant groups shown by DGGE/TGGE (Felske et al. 1999; Ellis et al. 2003) and other culture-independent molecular methods (Kaiser et al. 2001; Pearce et al. 2003). Therefore, in order to have a broader picture of microbial diversity, it is advisable to combine both culturing and non-culturing methods.

Similarly, fungi and yeasts other than A. bisporus could not be detected on the DGGE gel for compost, casing at pinning and mushroom samples. These samples were completely dominated by $A$. bisporus. In this study, the complete dominance of the mushroom fungal community by A. bisporus itself was likely due to the method used. The DGGE method revealed a broader perspective of members of a community. However, using the plating method, fungi and yeasts were detectable on MEA plates although they were few and of low diversity 
dominated by the genus Penicillium. This low level of fungi other than A. bisporus is satisfactory, especially in compost. Well prepared compost is produced in such a way that it selectively supports the growth of A. bisporus and is unfavourable for other fungi (Ross and Harris, 1983; Camp et al. 1990).

When comparing bacterial profiles of the compost, casing and mushroom samples using DGGE, compost populations were distinct from those of both the casing and mushrooms. This result is in agreement with Reddy and Patrick (1990), who isolated similar bacteria from the casing and the mushroom mycelium colonising it. Their results showed that these bacteria were not similar to those isolated from compost. They also concluded that bacterial isolates from compost had no effect on formation of mushroom fruit bodies. Profiles for fresh casing and casing at pinning were similar except that population densities increased at pinning, which is consistent with previous work (Siyoum et al. 2010). Both fresh mushrooms and mushrooms stored for eight days revealed few but dominant bacterial species on their profiles in comparison to casing and compost. These profiles were more similar to that of the casing. Our results suggest that the fresh mushroom surface could be selective to a specific group of bacteria dominated by Pseudomonas species. The whole profile also revealed that most bacteria on the mushroom surface originated very likely from the casing.

It is interesting that almost only Pseudomonas spp. were dominant on the mushroom profiles. On the casing profile, these species were less abundant (less intense bands) compared to what was obtained from the mushrooms. It was also clearly shown that Ewingella americana and certain Pseudomons spp. increased in abundance while a particular species, identified as a close relative of $P$. putida, could no longer be detected after the eight day of storage. It is 
interesting to note that $P$. putida was abundant on fresh mushrooms but not on stored ones, simulating a ready-to-sell product. This bacterium is well known for its role in fruit body initiation (Hayes et al. 1969; Noble et al. 2009) and our results indicated that it was not part of the postharvest spoilage syndrome associated with pseudomonads. The presence of pseudomonads and E. americana in mushrooms is in agreement with reports from different studies. Members of the genus Pseudomonas are well known as saprophytes and pathogens of mushrooms (Munsch and Alatossava, 2002; Sivanesan, 2003). The non-pseudomonad bacterium E. americana was also reported on mushrooms as both a pathogen (Inglis et al. 1996) and as a member of the indigenous micro-flora (Choudhury and Heinemann, 2006).

Phylogenetic analysis of bacteria from different samples - compost, casing and mushroom - revealed that generally, species from the same sample source were the most closely related. Nevertheless, it was also noted that some species from all three different sources were phylogenetically related to each other. In addition, five minor separate lineages comprising of compost and casing inhabiting bacterial species were formed on the phylogenetic tree. These lineages indicate that species from these two sample sources were diverse and several of them were not affiliated with known cultured bacteria. Ivors et al. (2000) reported a similar result in which several rDNA sequences from compost samples were unique and not related to previously identified species. Most of the sequences that were not affiliated with known cultured species in our study originated from excised DGGE bands of compost and casing samples. These results suggest that DGGE could reveal species that were not cultured previously and could possibly be novel. 
The phylogenetic tree of yeasts from compost, casing and mushroom samples was relatively simple, consisting of two lineages. The first lineage consisted of sequences predominantly from compost samples. Two sequences from mushroom samples were also affiliated with this lineage. The second lineage contained samples from casing and one sequence from compost. The phylogenetic tree for yeasts consisted of sequences from cultured species only, except one sequence from fresh casing sample of DGGE. Our results indicated that yeasts from compost samples were more diverse than those from casing. Four out of six yeast species from casing samples were closely related to Candida sp. including the one obtained from DGGE. The two species were closely related to each other but grouped with the lineage of yeasts from compost samples, although at a distant level.

In samples tested, yeast species originating from compost and casing samples were not closely related while yeasts from mushroom samples were closely related to those from compost samples. Although this result needs further investigation, it provides some background information on diversity and relationship of yeasts in compost, casings and edible mushrooms obtained from production, storage and marketing. A significant increase in yeast colonies were recorded after mushrooms were stored simulating retail practice at $4^{\circ} \mathrm{C}$ for four, eight and twelve days. Little information is available on spoilage of mushrooms caused by yeasts. Koorapati et al. (2004) and Chikthimmah (2006) reported on the control of microbial spoilage after product irradiation. In their experiment, irradiation reduced all microbial counts including bacteria, yeasts and moulds, and prolonged mushroom shelf life. However, it was not clear from their studies whether yeasts also contributed to the spoilage. A general observation in our study (unpublished data) was that spoilage was associated with superficial slimy yeast growth. Future studies should focus on determining the role of yeasts in mushroom spoilage at retail-end. 
The unique approach reported in this paper that used a combination of methods (cultural and non-cultural) to better understand microbial dynamics of mushrooms from seeding through growth, postharvest up to ready-to-eat at the consumer-end of the supply chain contribute towards a better understanding of what constitutes a healthy edible mushroom. This information can be used in developing national guidelines for total microbial loads of fresh mushrooms within a food safety compliance framework. A total microbial load of log CFU/g 4.4 to 9.4 has been reported for cultivated and wild mushrooms (Venturini et al. 2011). Doores et al. (1987) found that bacterial populations during postharvest storage at $13{ }^{\circ} \mathrm{C}$ increased from an initial load of $\log$ CFU/g 7 to almost $\log$ CFU/g 11 over a 10-day storage period. In our studies fresh white button mushrooms carried an average bacterial load of log CFU/g 5.8 increasing to a maximum of $\log$ CFU/g 7.6 when stored at $4{ }^{\circ} \mathrm{C}$ for 12 days. A normal microflora of healthy mushrooms at the point of harvest can represent a $\log \mathrm{CFU} / \mathrm{g} 4$ - 5 that reflect a healthy climax bacterial community. Bacterial microbial loads can be expected to increase to log CFU/g 7-9 depending on the storage conditions. In the work done by Doores et al. (1987) an increase in Pseudomonas populations to a $\log \mathrm{CFU} / \mathrm{g} 6$ were attributed to quality deterioration and brown blotch development.

\section{Acknowledgments}

This research was funded by the South African Mushroom Farmers Association (SAMFA), National Research Foundation (NRF) and the Technology and Human Resources for Industry Programme (THRIP) (a partnership programme funded by the Department of Trade and Industry and managed by the NRF). We would like to thank Dr. L. Meyer, Ms R. Jacobs, for molecular advice and assistance, as well as Ms A. Redmond for technical assistance. We also would like to thank the commercial farm for providing research materials. 


\section{References}

Abad M, Noguera V, Martínez-Corts J (1989) The effect of sedge peat-based media and controlled-release fertilizer on the growth of begonia, French marigold and geranium. Acta Hortic 246:199-212

Amann RI, Ludwig W, Schleifer K H (1995) Phylogenetic identification and in situ detection of individual microbial cells without cultivation. Microbiol Rev 59:143-169

Burton KS, Noble R (1993) The influence of flush number, bruising and storage temperature on mushroom quality. Postharvest Biol Tec 3:39-47

Camp HJMO, Stumm CK, Straatsma G, Derikx PJL, van Griensven JLD (1990) Hyphal and mycelia interactions between A. bisporus and Scytalidium thermophilum on agar media. Microb Ecol 19:303-309

Chikthimmah N (2006) Microbial ecology of mushroom casing soils and preharvest strategies to enhance safety and quality of fresh mushrooms. Ph.D. Thesis, Pennsylvania State University, USA

Choudhury PR, Heinemann JA (2006) The general secretory pathway of Burkholderia gladioli pv. agaricicola BG164R is necessary for cavity disease in white button mushrooms. Appl Environ Microbiol 72:3558-3565

Doores S, Kramer M, Beelman R (1987) Evaluation and bacterial populations associated with fresh mushrooms (Agaricus bisporus). In: Cultivating Edible Fungi. Wuest PJ, Royce DL, 
Beelman RB (eds) Developments in Crop Science 10, Amsterdam: Elsevier Science Publishers, pp 283-94

Drancourt M, Bollet C, Carlioz A, Martelin R, Gayral J-P, Raoult D (2000) 16S Ribosomal DNA sequence analysis of a large collection of environmental and clinical unidentifiable bacterial isolates. J Clin Microbiol 38:3623-3630

Eakin JH (1969) Let's know more about peat. Mushroom News 17:12-15

Eicker A, van Greuning M (1989) Economical alternatives for topogenous peat as casing material in the cultivation of Agaricus bisporus in South Africa. S Afr J Plant Soil 6:129-135

Ellis RJ, Morgan P, Weightman AJ, Fry JC (2003) Cultivation dependent and -independent approaches for determining bacterial diversity in heavy-metal-contaminated soil. Appl Environ Microbiol 69:3223-3230

Everett KDE, Bush RM, Andersen AA (1999) Emended description of the order Chlamydiales, proposal of Parachlamydiaceae fam. nov. and Simkaniaceae fam. nov., each containing one monotypic genus, revised taxonomy of the family Chlamydiaceae, including a new genus and five new species, and standards for the identification of organisms. Int J Syst Bacteriol 49:415-40

Felske A, Wolterink A, van Lis R, de Vos WM, Akkermans AD (1999) Searching for predominant soil bacteria: $16 \mathrm{~S}$ rDNA cloning versus strain cultivation. FEMS Microbiol Ecol $30: 137-145$ 
Fermor TR, Wood DA (1981) Degradation of bacteria by Agaricus bisporus and other fungi. J Gen Microbiol 126:377-387

Fermor T, Lincoln S, Noble R, Dobrovin-Pennington A, Colauto N (2000) Microbiological properties of casing. In: Van Griensven LJLD (ed) Science and Cultivation of Edible Fungi. Balkema, Rotterdam, pp 447-454

Fett WF, Wells JM, Cescutti P, Wijey C (1995) Identification of exopolysaccharides produced by fluorescent pseudomonads associated with commercial mushroom (Agaricus bisporus) production. Appl Environ Microbiol 61:513-517

Fjellbirkeland A, Torsvik V, Øvereås L (2001) Methanotrophic diversity in an agricultural soil as evaluated by denaturing gradient gel electrophoresis profiles of $p m o A, m x a F$ and 16S rDNA sequence. Anton Leeuwenhoek 79:209-217

Fordyce CJR (1970) Relative numbers of certain microbial groups present in compost used for mushroom (Agaricus bisporus) propagation. Appl Microbiol 20:196-199

Garbeva P, van Veen JA, van Elsas JD (2004) Microbial diversity in soil: selection of microbial populations by plant and soil type and implications for disease suppressiveness. Annu Rev Phytopathol 42:243-70

Hayes WA, Randle P, Last FT (1969) The nature of microbial stimulus affecting sporophore formation in Agaricus bisporus (Lange) Sing. Ann Appl Biol 64:177-187 
Inglis PW, Burden JL, Peberdy JF (1996) Evidence for the association of the enteric bacterium Ewingella americana with internal stipe necrosis of Agaricus bisporus. Microbiology 142:32533260

Ivors KL, Collopy PD, Beyer DM, Kang S (2000) Identification of bacteria in mushroom compost using ribosomal RNA sequence. Compost Sci Util 8:247-253

Kaiser O, Puhler A, Selbitschka W (2001) Phylogenetic analysis of microbial diversity in the rhizoplane of oilseed rape (Brassica napus cv. westar) employing cultivation-dependent and cultivation-independent approaches. Microb Ecol 42:136-149

Koorapati A, Foley D, Pilling R, Prakash A (2004) Electron-beam irradiation preserves the quality of white button mushrooms (Agricus bisporus) slices. J Food Sci 69:SNQ25-29

Labuschagne PM (1995) Casing media for Agaricus bisporus cultivation in South Africa. M.Sc. Thesis, University of Pretoria, South Africa

Miller FC, Harper ER, Macauley BJ (1989) Field examination of temperature and oxygen relationships in mushroom composting stacks-consideration of stack oxygenation based on utilisation and supply. Aust J Exp Agr 29:741-750

Miller N, Gallespie JB, Doyle OPE (1995) The involvement of microbiological components of peat based casing materials. Mushroom Sci 14:313-321

Munsch P, Alatossava T (2002) Several pseudomonads, associated with the cultivated mushrooms Agaricus bisporus or Pleurotus sp., are hemolytic. Microbiol Res 157:311-315 
Noble R, Dobrovin-Pennington A, Hobbs PH, Pederby J, Rodger A (2009) Volatile C8 compounds and pseudomonads influence primordium formation of Agaricus bisporus. Mycologia 101:583-591

Orgiazzi A, Bianciotto V, Bonfante P, Daghino S, Ghignone S, Lazzari A, Lumini E, Mello A, Napoli C, Perotto S, Vizzini A, Bagella S, Murat C, Girlanda M (2013) 454 Pyrosequencing analysis of fungal assemblages from geographically distant, disparate soils reveals spatial patterning and a core mycobiome. Diversity 5:73-98. doi:10.3390/d5010073

Øvereås L, Forney L, Daae FL, Torsvik V (1997) Distribution of bacterioplankton in meromictic lake Sælenvennet as determined by denaturing gradient gel electrophoresis of PCR amplified gene fragments coding for 16S RNA. Appl Environ Microbiol 63:3367-3373

Pearce DA, van der Gast CJ, Lawley B, Ellis-Evans JC (2003) Bacterioplankton community diversity in a maritime Antarctic lake, determined by culture-dependent and culture-independent techniques. FEMS Microbiol Ecol 45:59-70

Peters S, Koschinsky S, Schwieger F, Tebbe CC (2000) Succession of microbial communities during hot composting as detected by PCR-single-strand-conformation polymorphism-based genetic profiles of small-subunit rRNA genes. Appl Environ Microbiol 66:930-936

Ranjard L, Lehon PH, Mougel C, Schehrer L, Merdinoglu D, Chaussod R (2003) Sampling strategy in molecular microbial ecology: influence of soil sample size on DNA fingerprinting analysis of fungal and bacterial communities. Environ Microbiol 5(11):1111-1120 
Reddy MS, Patrick ZA (1990) Effect of bacteria associated with mushroom compost and casing materials on basidiomata formation in Agaricus bisporus. Can J Plant Pathol 12:236-242

Riahi H, Eskash A, Shariatmadari Z (2011) Effect of bacterial and cyanobacterial culture on growth, quality and yield of Agaricus bisporus. Proceedings of the 7th International Conference on Mushroom Biology and Mushroom Products (ICMBMP7)

Ross RC, Harris, PJ (1983) An investigation into the selective nature of mushroom compost Sci Hortic 19:55-64

Ryckeboer J, Mergaert J, Vaes K, Klammer S, de Clercq D, Coosemans J, Insam H, Swings J (2003a) A survey of bacteria and fungi occurring during composting and self-heating processes. Ann Microbiol 53:349-410

Ryckeboer J, Mergaert J, Coosemans J, Deprins K, Swings J (2003b) Microbiological aspects of biowaste during composting in a monitored compost bin. J Appl Microbiol 94:127-137

Sivanesan D (2003) Diversity among bacteria causing blotch disease on the commercial mushroom, Agaricus bisporus. M.Sc. Thesis, Brock University, Ontario

Siyoum NA, Surridge K, Korsten L (2010) Bacterial profiling of casing materials for white button mushrooms (Agaricus bisporus) using denaturing gradient gel electrophoresis. S Afr J Sci doi: 10.4102/sajs. v106i9/10.253

Straatsma G, Samson RA, Olijnsma TW, Camp HJMOD, Gerrits JPG, van Griensven LJLD (1994) Ecology of thermophilic fungi in mushroom compost, with emphasis on Scytalidium 
thermophilum and growth stimulation of Agaricus bisporus mycelium. Appl Environ Microbiol $60: 454-458$

Székely AJ, Sipos R, Berta B, Vajna B, Hajdú C, Márialigeti K (2009) DGGE and T-RFLP Analysis of Bacterial Succession during Mushroom Compost Production and Sequence-aided TRFLP Profile of Mature Compost. Microb Ecol 57:522-533

Venturini ME, Reyes JE, Rivera CS, Oria R, Blanco D (2011) Microbiological quality and safety of fresh cultivated and wild mushrooms commercialized in Spain. Food Microbiol 28:1492-1498

Verhoeven JTA (1986) Nutrient dynamics in minerotrophic peat mires. Aquat Bot 25:117-137

Wells JM, Sapers GM, Fett WF, Butterfield JE, Jones JB, Bouzar H, Miller FC (1996) Postharvest discoloration of the cultivated mushroom Agaricus bisporus caused by Pseudomonas tolaasii, P. 'reactans', and P. 'gingeri'. Phytopathology 86:1098-1104

White TJ, Bruns T, Lee S, Taylor JW (1990) Amplification and direct sequencing of fungal ribosomal RNA genes for phylogenetics. In: Innis MA, Gelfand DH, Sninsky JJ, White TJ (eds) PCR protocols: A Guide to Methods and Applications. Academic Press, New York, pp 315-322 